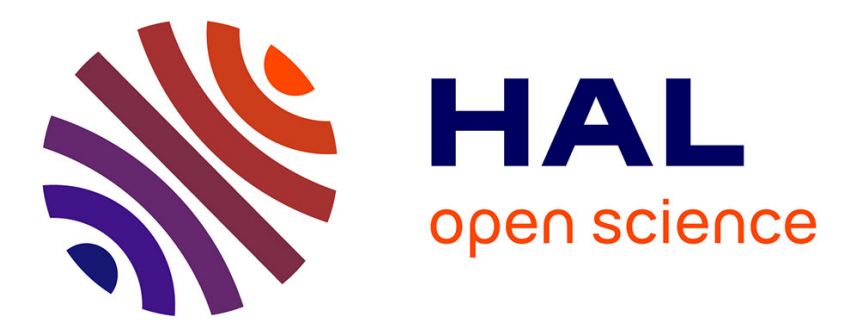

\title{
Optimization and simulation based approach for an arrival and departure manager tool
}

Paolo Maria Scala, Miguel Antonio Mujica Mota, Daniel Delahaye

\section{To cite this version:}

Paolo Maria Scala, Miguel Antonio Mujica Mota, Daniel Delahaye. Optimization and simulation based approach for an arrival and departure manager tool. WSC 2016, Winter Simulation Conference, Dec 2016, Washington, United States. pp.E-ISBN: 978-1-5090-4486-3, 10.1109/WSC.2016.7822416 . hal01488669

\section{HAL Id: hal-01488669 \\ https://hal-enac.archives-ouvertes.fr/hal-01488669}

Submitted on 19 Mar 2019

HAL is a multi-disciplinary open access archive for the deposit and dissemination of scientific research documents, whether they are published or not. The documents may come from teaching and research institutions in France or abroad, or from public or private research centers.
L'archive ouverte pluridisciplinaire HAL, est destinée au dépôt et à la diffusion de documents scientifiques de niveau recherche, publiés ou non, émanant des établissements d'enseignement et de recherche français ou étrangers, des laboratoires publics ou privés. 


\title{
OPTIMIZATION AND SIMULATION BASED APPROACH FOR AN ARRIVAL AND DEPARTURE MANAGER TOOL
}

\author{
Paolo Scala, Miguel Mujica Mota \\ Amsterdam University of Applied Sciences \\ Weesperzijde 190 \\ Amsterdam, 1097 DZ, THE NETHERLANDS \\ Daniel Delahaye \\ ENAC \\ 7 Avenue Edouard Belin \\ Toulouse, 31400, FRANCE
}

\begin{abstract}
This work proposes a methodology for developing an airport arrival and departure manager tool. This methodology employs optimization together with simulation techniques for improving the robustness of the solution. An arrival and departure manager tool is intended to help air traffic controllers in managing the inbound and outbound traffic without incurring in conflicts or delays. In this context, air traffic controllers need to have a tool able to help them to make the right decisions in a short time horizon. The main decisions taken in the present methodology for each aircraft are: entry time and entry speed in the airspace and push back time at the gate. The objective of this methodology is to have a smooth flow of aircraft both in the airspace and on the ground. Preliminary tests were made using Paris Charles de Gaulle Airport as case study, and the results show that conflicts were sensibly reduced.
\end{abstract}

\section{INTRODUCTION}

Capacity at airports has become a very delicate problem due to the increase of traffic demand and the scarcity of resources at airports. Figures from Eurocontrol say that the traffic in Europe has been increased by $1.5 \%$ from 2014 to 2015 , and a further growth is already forecasted for the next years. On the other hand figures of delays have increased at the same time, where $34 \%$ and $38 \%$ of the European flights were delayed on departures (Eurocontrol, 2016).

Terminal manoeuvring area (TMA), which is the airspace that surrounds the airports, is a really congested airspace area because of the converging flow of aircraft landing and departing from the airport and due to the lack of capacity both on the airspace and on the ground, As a consequence, the work load of the air traffic controllers is getting even heavier, since they need to process all this flow of aircraft ensuring the safety and avoiding to cause too many delays. In these circumstances, they need a tool that is able to help them in managing the traffic at airports, inbound and outbound. Arrival and Departure Manager (A-MAN and D-MAN) tools have already been developed in Europe and elsewhere since many years (Eurocontrol, 2010; PHARE), the objective of these tools is to obtain a smooth traffic with an efficient use of the airspace.

This work proposes to link A-MAN and D-MAN together in order to have a better management of the overall traffic considering both arrival and departing flow of aircraft. The main contribution is that it considers the application of optimization and simulation techniques together in order to come up with a more robust solution. The optimization model has been developed employing a sliding window approach and 
the solution was found by the use of a meta-heuristic. The simulation model has been developed using a discrete event simulation software.

\section{METHODOLOGY}

The methodology presented in this work is constituted by three main steps (figure 1). The first step aims at modelling the airport taking into account both airspace and airside. In this case the airside was modelled in a "macro" level, where runway, taxiway and terminals were modelled as servers with a specific capacity, while the airspace was modelled taking into account the existing landing routes (Standard Terminal Arrival Routes) in the TMA. The second step consists in the implementation of an optimization model, employing a sliding window approach and a meta-heuristic to solve the problem and obtaining an (sub)optimal solution for the conflict detection and resolution and sequencing problem for both the landing and the departing case. In this case four types of conflicts were identified: airspace conflicts, any loss of separation minima between two consecutive aircraft; runway conflicts, any time the capacity of the runway is exceeded; taxiway conflicts, any time the capacity of the taxiway network is exceeded; terminal conflicts, any time the capacity of the terminal is exceeded. In the optimization mode the decision variable taken into account for each aircraft are three: Entry Time (in the airspace), Entry Speed (in the airspace) and Pushback time (on the ground). Finally, in the third step, the solution obtained from the optimization model was tested using a simulation model with the scope of validating its effectiveness and feasibility. The main objective is to have a free conflict scenario, both for airspace and airside, and so have a smooth flow of aircraft in the airspace and on the ground avoiding congestion.

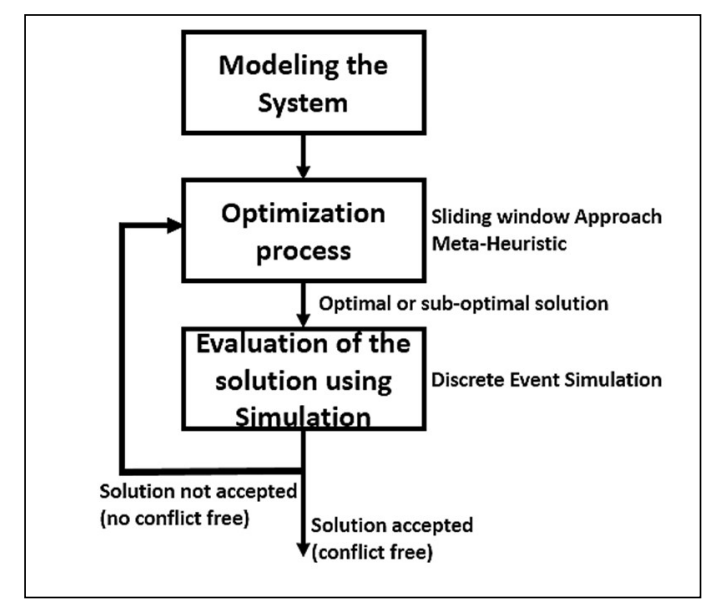

Figure 1 Methodology steps

\section{REFERENCES}

Eurocontrol, Industry monitor. Issue N180-181-182. 2016.

Eurocontrol, Arrival Manager, Implementation Guidelines and Lessons Learned. Edition number 0.1. Edition date: 17 December 2010.

PHARE Advanced Tools Departure Manager. PHARE/CENA/PAT-6.8.7.3.4/FR;0.3. 